\title{
Dentro e Fora do Palco: Projeto Autoral
}

Só traduzimos nossas emoções: sempre falamos de nós mesmos.

(Marguerite Yourcenar)

$\mathrm{U}$

m processo de investigação artística envolve muitos objetivos. $\mathrm{Na}$ pesquisa ora desenvolvida, destaca-se um propósito claro: a criação de um espetáculo unipessoal no qual o ator seja o verdadeiro autor da cena. A consolidação de Meus caros amigos e seu enfrentamento a diferentes públicos deu conta desse objetivo. Várias ações associadas a essa intenção inicial foram elaboradas de maneira consciente para fortalecer a ideia de autoria, mas outras foram aparecendo de modo inesperado, as quais acabaram reformulando o conceito de autoria que, no começo, fazia parte do meu imaginário. Essas ações são as que se descrevem neste capítulo.

Por ser uma inquietação tão importante no meu percurso a possibilidade de apresentar na cena um dizer próprio sem abandonar o ofício de ator, a busca da categoria ator-antor se converteu em um guia que conduziu todas as intenções do processo criativo. No entanto, uma pergunta aparecia constantemente nesse caminho: por que ir atrás dessa noção de autor quando já alguns teóricos promoveram sua morte?

A categoria autor há muito tempo se converteu em um conceito problemático. De fato, a conferência citada no primeiro capítulo deste livro, O que é um autor?, de Michel Foucault (2001), publicada inicialmente em 1969, apareceu depois de objeções recebidas pelo filósofo francês relacionadas à utilização de nomes próprios para 
falar de tecidos discursivos atribuídos a pessoas particulares, mas que poderiam atingir ideias que ultrapassavam visões individuais do mundo. Aparentemente, e do ponto de vista dos críticos de Foucault, o uso da palavra autor contrariava as intenções deste. Por isso, ele acabou publicando o que entendia por função autoral.

A polêmica apareceu no mundo das ideias um ano antes (1968), quando Roland Barthes declarou a morte do autor, tal como se colocou também nos pressupostos teóricos deste trabalho. Segundo Juan Manuel Zapata (2011), desde então, a noção de autor se converteu em um tabu. A ideia de um sujeito proprietário e responsável por uma obra, apto para exercer sua autoridade sobre ela, parecia incomodar a toda uma geração para a qual a autoridade não era outra coisa senão um tropeço da história (Zapata, 2011). É por esse motivo que se faz necessário voltar ao tema da autoria neste capítulo final, no qual se pretende dilucidar o conceito ator-autor no contexto do espetáculo unipessoal.

Como se assinalou no primeiro capítulo, Foucault (2001) coincide com Barthes ao reconhecer que a figura do autor está diretamente associada com a individualização das ideias, o que também tem relação com aquele costume da crítica ortodoxa de explicar a obra a partir da vida do seu autor (pessoa física). Para ambos os filósofos, isso não faz sentido.

Sabemos agora que um texto não é feito de uma linha de palavras libertando um sentido único, de certo modo teológico (que seria a mensagem do Autor-Deus), mas um espaço de dimensões, onde se casam e se contestam escritas variadas, nenhuma das quais é original: o texto é um tecido de citações, saídas dos focos da cultura. (Barthes, 2004, p.4)

O leitor terá notado o uso da palavra texto, e não de obra no discurso de Barthes. Isso se relaciona com uma problemática que aparece muito bem definida no campo da literatura, espaço no qual a categoria autor também é mais clara. Para os interesses desta pesquisa, a discussão sobre o papel do autor, sua existência, sua desaparição e até a possibilidade de sua ressurreição é fundamental para contextualizar o que se pretende 
desenvolver no caso do trabalho do ator que quer ser autor de sua própria obra. Não é possível desconhecer que o tema da autoria tem sido discutido mais vastamente no campo das letras. Do ponto de vista de quem escreve estas páginas, isso não representa nenhum tipo de obstáculo até porque, no teatro, o dramaturgo, o escritor continua sendo chamado de autor. Além disso, acredita-se que a relação de proximidade entre a literatura e as artes cênicas é mais enriquecedora do que limitante ${ }^{1}$.

Mas, para evitar confusões, será dado aqui um sentido cênico à palavra texto. Para isso, vamos levar em conta as considerações de Enrique Buenaventura. O artista colombiano assevera que é um lugar comum acreditar que o texto teatral é o texto literário que posteriormente será representado, e que essa ideia se reduz a uma época relativamente recente restringida à tradição teatral burguesa europeia dos séculos XVIII, XIX e XX (Buenaventura, 1984). O mestre da criação coletiva colombiana entende por texto teatral um sistema de textos e códigos (visuais e sonoros) que não podem se produzir sem a mediação dos espectadores, os quais dão a ele sua dimensão de espetáculo vivo, único e irrepetível (Buenaventura, 1984).

Essa consideração de Buenaventura também está muito relacionada com os interesses desta pesquisa porque contradiz aquela ideia de que o texto literário é o elemento principal e único de criação teatral. Segundo ele, essa centralização do literário reduz os outros componentes do espetáculo ao papel de intérpretes (Buenaventura, 1984). Por esses motivos, quando se falar de texto teatral neste capítulo, entenda-se esse sistema de códigos que dará conta do acontecer cênico. Assim, a

1 O mestre do teatro colombiano, e também pilar da criação coletiva, Enrique Buenaventura, expressou em várias ocasiões a desconfiança que lhe produzia a relação que críticos e teóricos construíam entre literatura e teatro. Em um texto no qual fala de dramaturgia do ator, o artista começa com a seguinte frase: "O Teatro não é um gênero literário" (Buenaventura, 1985, parágrafo $1^{\circ}$, tradução minha). Essa é uma posição usual no meio teatral. Raymond Williams (2010), ao contrário, pensa que essa separação é profundamente limitadora, sobretudo para os estudos teatrais. Esta pesquisa coincide com Buenaventura ao não considerar o cênico produto do literário, mas defende, como Williams, que ambas as disciplinas têm muito a contribuir entre si. 
palavra texto, utilizada por diferentes teóricos para falar de autoria, terá na nossa lógica a categoria de obra.

Voltando a Barthes, e agora sim usando a palavra obra, deve ser considerado que o mais comum na prática crítica é que: “[...] a explicação da obra é sempre procurada do lado de quem a produziu, como se, através da alegoria mais ou menos transparente da ficção, fosse sempre afinal a voz de uma só e mesma pessoa, o autor, que nos entregasse a sua "confidência'" (Barthes, 2004, s/p., itálico no original).

A ideia que Barthes está colocando ao falar da morte do autor é a dessa entidade compreendida como individualidade; é aquela de considerar que a obra é produto exclusivo de uma genialidade individual e afastada da multiplicidade de discursos que atravessam a condição humana. Efetivamente, é inútil e quase inservível promover uma explicação da obra exclusivamente a partir da pessoa física que a escreveu, compôs ou planejou. Mas, como já o colocou Foucault, reconhecer a morte do autor não faz com que se possa desconhecer a existência da função autor. Essa perspectiva é fundamental para a consolidação dos objetivos desta pesquisa.

Para aprofundar esse assunto, a proposta de Juan Manuel Zapata, que fala não só da morte do autor, mas também de sua ressurreição, oferece pontos de partida para entender a função do autor no mundo contemporâneo. Zapata inicia seu estudo a partir de Barthes e de Foucault para mudar o foco da questão do que é um autor (tema que interessou claramente a Foucault) à pergunta de como se constrói um autor. $\mathrm{Na}$ continuação, umas palavras do pesquisador que se citam aqui não só porque resumem a lógica de sua abordagem, mas também pelos termos cênicos nos quais ela é apresentada:

[...] a construção autoral não se reduz unicamente às operações ou exegeses textuais às quais estão submetidas as obras em um esforço de catalogação e valorização, mas que implica também a encenação de um projeto autoral, uma teatralização da figura do autor, na qual participam não só essa personagem que assina a obra, mas as diferentes instâncias que compõem a vida literária. (Zapata, 2011, p. 42, tradução minha, itálico no original) 
O projeto autoral será, então, o que determinará como se constrói um autor. Zapata (2011) esclarece que a existência do autor depende de sua capacidade para se fazer notar, fazer-se visível, criar uma identidade reconhecível para o público. Isso se relaciona com o propósito desta pesquisa na medida em que tenta visibilizar o ato criativo do ator, o qual é reconhecido habitualmente na sua função interpretativa, mas escassamente na sua função autoral.

Essa atitude de se tornar visível, sob a perspectiva de Zapata, constitui o início do projeto autoral e faz referência à necessidade de ressuscitar essa figura do autor em um mundo no qual, mesmo morto teoricamente, continua sendo uma entidade viva na prática, tal como acontece no contexto acadêmico no qual estão imersos pesquisadores, cientistas, artistas, docentes e discentes.

Juan Manuel Zapata (2011) chama de projeto autoral o mecanismo pelo qual o produtor cultural (o aspirante a autor) assume simultaneamente uma posição discursiva e uma postura no campo que lhe concerne. Nesse sentido, trata-se de uma estratégia consciente que se desenvolve em dois sentidos paralelos: o plano textual e o plano comportamental (Zapata, 2011). Não é, então, a intenção de se constituir autor o que dá essa categoria ao indivíduo. É necessário entender que a criação discursiva não é a única coisa que possibilita o reconhecimento autoral, mas sim uma soma de ações no campo artístico que está associada com a difusão e a postura que se estabelece em relação com o discurso que se promove por meio da obra.

A proposta de Juan Manuel Zapata foi muito importante nesta pesquisa porque esclareceu que essa busca pela figura de um ator-autor não se achava unicamente na construção da obra e na criação de um discurso próprio. Isso representou a constatação de que a criação de Meus caros amigos só era o início desse projeto autoral e que construir um espetáculo que levasse ao máximo minha ideia de autonomia criativa era só uma parte do que eu tentava. Era claro que, até esse momento, só tinha definido o objeto sobre o qual reivindicaria a autoria. Mas, como já foi anotado nas palavras de Zapata, era necessário desenvolver uma estratégia para me fazer notar como um ator que é autor de sua própria obra. 
O espetáculo unipessoal e todo o seu processo criativo evidenciou a busca dessa criação discursiva da qual posso me considerar autor. No entanto, esclarecer que esse exercício é só o começo da consolidação de um projeto autoral me permitiu entender que essa categoria não seria conquistada unicamente no palco. Era preciso empreender ações em outros cenários.

O plano textual já estava definido pela criação em si de Meus caros amigos, de sua materialidade como espetáculo teatral. Eu precisava entender aquele outro plano, o comportamental, o qual desenvolveu ações que, embora eu tenha considerado necessárias desde o início do processo, só entendi que faziam parte de meu projeto autoral a partir da reflexão que este capítulo apresenta.

Sobre esse assunto, Zapata (2011) assevera: “[...] toda produção discursiva contempla um enunciado e a encenação dele, esse ato discursivo que é a condição e o produto mesmo da enunciação" (p. 49). Como produção discursiva, como obra artística, Meus caros amigos apresenta uma série de enunciados que denotam sua carga em termos de conteúdo. Portanto, pode ser estudado como texto teatral, seguindo a ideia de Enrique Buenaventura colocada acima, isto é, como um sistema de códigos que transforma esse texto teatral em um espetáculo vivo e único. Sua criação define o plano textual da autoria perseguida.

Mas existe uma série de circunstâncias, decisões, eventos e ações que rodeou a aparição do espetáculo no campo teatral. Isso se relaciona com considerações que cercaram a etapa de divulgação e de confrontação com o público, assim como o discurso teórico, acadêmico e artístico que acompanhou as apresentações do espetáculo e a divulgação da proposta de pesquisa. Essas ações definiriam o campo comportamental do projeto autoral e demonstrariam a "encenação" do enunciado da qual fala Zapata.

O seguinte capítulo descreve essas ações dividindo-as em dois planos: o textual (que estará relacionado com o cênico) e o comportamental (relacionado com as ações que acompanharam a divulgação da obra). Esses dois planos pretendem abarcar a noção de projeto autoral, entendido como estudo sistemático da função autor. Considerando que se trata de planos que nem sempre se encontram separados em termos de concepção e de execução, vários aspectos podem ser analisados a partir 
dos dois pontos de vista. Além disso, os dois se encontram relacionados com três movimentos inseparáveis que Zapata (2011) descreve para falar do projeto autoral como estudo sistemático: 1) os modos de inscrição da "presença autoral" nos conteúdos discursivos publicados pelo produtor cultural; 2) as situações de enunciação desses discursos como manifestações de uma posição particular no campo artístico e 3) a recepção e a circulação deles.

\section{Autoria da cena}

Meus caros amigos, finalmente, se consolidou como uma obra artística que entrou no circuito teatral e foi vista por diferentes públicos. Como realidade cênica, esse espetáculo unipessoal se converteu no resultado de um processo criativo que procurou o estabelecimento de um discurso particular, no qual o ator se apropriava de diversos materiais para se vincular à autoria do espetáculo.

Como parte do projeto autoral que estava construindo, chegar a esse resultado me dava a enunciação da qual fala Zapata. A conformação da obra como realidade cênica proporcionou o plano discursivo que me permitia começar a me considerar autor de "algo". Existia já uma obra artística real, recebida por um público, objeto de algumas críticas, apresentada em diferentes cidades e teatros e com participações e reconhecimentos em alguns festivais de caráter internacional ${ }^{2}$.

Efetivamente, existia já um conteúdo discursivo que evidenciava uma presença autoral minha, uma obra artística que, embora tivesse uma vida curta, podia considerar bem-sucedida. Não me refiro à expressão bem-sucedida como experiência crítica ou aceitação unânime

2 Até 2017, o espetáculo Meus caros amigos já foi apresentado em vários países, como Brasil, Colômbia, Argentina, Estados Unidos, México e Peru. Recebeu o prêmio à melhor dramaturgia no Terceiro Festival Rosa de Teatro de Bogotá (Colômbia) e o prêmio ao melhor texto original (monólogo) no Quinto Festival Internacional de Teatro de Pequeno Formato de Miami (Estados Unidos). 
de determinado público, mas ao que Luigi Pareyson (1993) considera quanto a isso: "na arte a obra bem-sucedida satisfaz a uma legalidade e a uma finalidade instaurada por ela mesma" (p. 67).

A experiência de apresentar o espetáculo em diferentes contextos permitiu afinar as leis que o processo criativo em si propôs e ajustar a obra até alcançar uma forma que me satisfez em relação ao que, como autor, queria apresentar. " $\mathrm{Na}$ arte o critério do resultado é o próprio resultado, e a obra se torna o que é graças ao resultado obtido, e o bom êxito se deve à adequação de todos esses dados [as exigências e as leis próprias da obra]" (Pareyson, 1993, p. 67).

Esse reconhecimento de critérios e de propósitos não só aperfeiçoou o próprio espetáculo, mas também minha função autoral dentro dele. O sucesso do espetáculo radicou justamente no encontro de uma voz, na depuração de um discurso próprio, já que o objetivo principal da criação do espetáculo unipessoal era a projeção de um dizer meu —a expressão de uma inquietação particular-. A consolidação desse discurso e a chegada ao ponto de poder depurar e moldar esse dizer representava o êxito do processo criativo. Mas o sucesso do resultado se deve também, como anotado por Pareyson, à adequação da obra às regras que possibilitaram a aparição da forma, como foi explicado no capítulo anterior.

Mediante esse ato [a invenção] se faz a obra e ao mesmo tempo se vai gradualmente descobrindo o modo como pode e deve ser feita. Mas só se chega ao resultado se a obra sair conforme essas leis e esses fins. De sorte que o critério do resultado reside propriamente na legalidade ou finalidade da operação específica, embora essas não atuem, de antemão predeterminando a regra [...] (Pareyson, 1993, p. 67)

O reconhecimento das regras particulares que possibilitaram a aparição da forma do espetáculo, isto é, os métodos usados no ato da invenção, nessa ordem de ideias, permitiriam determinar as estratégias autorais na conformação do espetáculo. 


\section{Estratégias autorais na criação de Meus caros amigos}

No início do processo criativo, a associação tradicional entre autoria e autoridade era o que primava como ponto de partida. Reivindicar o controle sobre todos os elementos da cena parecia ser a premissa que permitiria alcançar a ansiada categoria de ator-autor. Nas minhas primeiras projeções, controle e autoria eram conceitos que se entrelaçavam. No entanto, o desenvolvimento da pesquisa, como se descreveu anteriormente, mostrou que o controle consciente não tem, obrigatoriamente, relação com o processo de criação artística. Nada funcionou, no caminho empreendido, por imposição.

Isso se expressou de múltiplas maneiras no resultado final. Em termos de intenções discursivas, por exemplo, eu queria falar da homossexualidade desprovida de qualquer ponto de vista moralizador. Tudo o que conscientemente queria pôr na cena se conduzia a essa direção — a admiração que me causa o discurso de André Gide está precisamente relacionada com esse fato-. Mas o espetáculo terminou falando de culpa. Representava isso uma espécie de traição ao meu eu autor ${ }^{3}$ ? Não. Descobri que a autoria, diferentemente do que pensava no começo, se constrói com a obra, não se trata de uma condição $a$ priori do indivíduo artista.

Marguerite Yourcenar, no seu Tratado do vão combate, no qual também fala de criação artística — seu protagonista alterna sua reflexão existencial com seu ofício como músico-, deu-me as palavras que me ofereceram resposta ao porquê de a culpa aparecer no meu discurso autoral. "Sempre acontece assim: nossas obras representam um período de nossa existência que já ultrapassamos na época na qual as escrevemos" (Yourcenar, 2002, p. 40, tradução minha).

A primeira quebra que experimentei com o conceito de autoria foi dada por essa experiência. Eu acreditava que o autor era quem dava as regras à obra, mas depois de Pareyson identifiquei que a

3 Nas seguintes páginas, aparecerá de novo a expressão eu autor para distingui-la de um eu ator ou intérprete. Será mantido o uso de itálico para evitar confusões na leitura. 
própria obra cria e se conduz pelos princípios que lhe são naturais, e que nenhuma imposição externa contribui com a consecução de sua forma bem-sucedida. De fato, o filósofo (1997) assinala o seguinte:

[o] artista é mais um espectador do que ator, mais receptáculo e veículo do que autor ou criador: a obra quase que se faz por isso mesma, organizando-se na sua atividade e tornando-a como que o instrumento de se próprio nascimento. No fundo o artista é passivo e inconsciente e segue ou, quando muito, secunda uma criação que se faz por si. (p. 99)

Aparentemente, a fala anterior contradiria o que até este momento tentei defender: a autoria como espaço no qual o ator deixa de ser veículo ou intermediário. Segundo Pareyson, o artista nunca deixa de sê-lo. Mas isso se relaciona diretamente com a obra, e não com discursos externos ao artista em si. O que efetivamente se transforma com a afirmação de Pareyson é a ideia de autoria que tinha antes de enfrentar o processo de Meus caros amigos, na qual o artista era o que dominava a experiência criativa, e não a obra a que ditava as regras.

O artista não é tão criador como quando, na sua atividade, se recorta a independência da forma, como quando a obra lhe impõe a sua própria vontade, no ato de ser produzida por ele, porque então torna-se evidente como ele, verdadeiramente, "criou", isto é, produziu alguma coisa de vivo e de autônomo, que se destaca dele e está em condições de viver por conta própria. O sinal mais evidente da criatividade é o fato de a iniciativa do artista culminar na autonomia da obra. (Pareyson, 1997, p. 103)

Não se trata de que Pareyson negue as qualidades criativas do artista, mas me parece que está apontando a entender o ato criativo como um exercício de escuta no qual a obra alcança sua forma bem-sucedida graças à capacidade do criador de atingir as próprias necessidades dela e as regras que ela mesma dita. Nesse sentido, a passagem que este livro pretende explicar seria a de ser veículo dos discursos de outros a sê-lo dos próprios. Não atingiria, portanto, a categoria de ator-autor 
por imposição. Seria uma estreita relação entre obra e artista a que determinaria as condições de minha autoria. Por um lado, a obra começou a ditar certas regras; mas, por outro, a pessoa do artista contribuiu com uma inventividade que vinha desde o começo do processo e fez com que ficassem rastos das considerações iniciais, mesmo transformados pelas condições da obra que se estava formando.

Então, como foi que se construiu o discurso autoral de Meus caros amigos? Para começar a responder a essa questão, é importante assinalar que nunca se partiu da ideia romântica do gênio criador, na qual tudo o que conforma a obra proviria da inspiração e da genialidade do artista. Nessa medida, o que me interessava desenvolver tinha mais a ver com a visão pós-moderna do conceito de autoria que aparece nos pressupostos teóricos desta pesquisa.

Jaime Alejandro Rodríguez (2004), já citado no primeiro capítulo, afirma que as obras pós-modernas tentam demonstrar que o processo criativo não é, de forma nenhuma, produto de uma inspiração divina ou de um dom especial. Isso faz com que esse tipo de obras se apresente como não totalidade, fragmentado e incompleto, com o interesse de promover a dupla produtividade, isto é, a construção discursiva tanto de quem a produz (o autor) quanto de quem a recebe (o leitor ou o espectador).

Isso é fundamental para entender uma das primeiras estratégias autorais desenvolvidas em Meus caros amigos. O espetáculo se apresenta para o público como uma experiência fragmentada. O protagonista convida seus amigos para falar da sua vida, mas só apresenta fragmentos aparentemente desconexos de sua experiência vital. Esses acontecimentos aparecem narrados sem uma ordem cronológica rigorosa e neles se alternam diferentes visões sobre a homossexualidade (grande revelação pessoal do protagonista), umas delas morais (sexualidade, religião e convenção social são discutidas em certos momentos), algumas da ordem intelectual (o protagonista chega até a afirmar que a educação uranista está diretamente relacionada com momentos de esplendor filosófico e artístico na história do ser humano) e outras simplesmente circunstanciais (a experiência homossexual como vivência da cotidianidade). O espectador está diante, assim, de uma história cheia de vazios. Imerso na ficção proposta, 
tem que completar a obra, estabelecer relações que não são dadas necessariamente pelo próprio espetáculo.

Como portador do discurso, nunca me interessou a ideia de criar um espetáculo que acabasse apresentando a homossexualidade como uma ideia fechada ou que "pontificasse" sobre o assunto. Pretendia a criação de uma obra que permitisse criar um diálogo com os espectadores, na qual eles sentissem que podiam ser parte da construção do discurso. Inclusive, interessava-me fazer perguntas diretas para os espectadores sobre o assunto.

Assim, a escolha dramatúrgica de estabelecer diálogo permanente com o público acaba sendo uma das estratégias que define as particularidades da ideia de autoria que se propôs no espetáculo. Ao converter a plateia em parte da ficção, estabelece-se uma convenção na qual o discurso se constrói entre as duas partes. Os espectadores de Meus caros amigos são abordados constantemente com perguntas sobre a questão principal debatida ou sobre a mesma ficção apresentada. Em alguns momentos, por exemplo, insta-se ao espectador a se perguntar sobre a experiência existencial — "Qual é o sentido da vida se a gente não faz dela uma experiência estética?" (Apêndice B)—; em outros, aparecem perguntas que se propõem com o intuito de que a plateia complete as referências que o espetáculo apresenta — “Jamais escutou a palavra 'uranismo'?” (Apêndice B)—; ou, simplesmente, deixa-se que o espectador pense em outras possibilidades de desenvolvimento da ficção - "O que teria significado minha vida se tivesse morrido naquele hospital, se não tivesse recebido o beijo doce da beleza?” (Apêndice B)- .

Esse tipo de abordagem faz com que o espectador seja constantemente convidado a completar a obra. Desse modo, o ator-autor do espetáculo não aparece como dono e senhor da enunciação, mas como aquele emissor que se interessa por algum assunto particular, por apresentá-lo à plateia e espera que ela o transcenda. Isso faz da autoria uma questão que não é exclusiva do portador do discurso e que, na prática em si, me permitiu entender que era o que realmente estava matando Barthes. Não é a ideia de autoria em si, mas a de um indivíduo mensageiro da verdade absoluta, dono do discurso, a que condenou Barthes. Meus caros amigos se encarrega bem disso. Como 
apresentarei na seguinte secção, a experiência de retroalimentação do público foi a grande reveladora dessa circunstância.

Não me colocando como dono do discurso e assumindo minha postura autoral não como autoridade, desde o início do processo, e em consonância com essa maneira mais contemporânea de entender a autoria, tive a certeza de que a imaginação, concebida ela como faculdade autônoma, não seria a fonte de inspiração para a criação do espetáculo. É por isso que, em vez de falar de imaginação, se fala de imaginário no contexto desta pesquisa, levando em conta que esse último conceito está mais intimamente relacionado com a ideia de construção a partir da experiência do mundo.

As múltiplas referências literárias e iconográficas que se escolheram como parte do meu imaginário sobre a homossexualidade para a criação do espetáculo, por exemplo, não são nada mais que fragmentos da cultura que, agora, depois da configuração final da obra, parecem peças de um quebra-cabeça. Existe uma estratégia autoral nesse exercício de apropriação que se traduz, não só na construção da ficção, mas também em vários aspectos da conformação do texto teatral.

As diferentes acepções que aparecem quando se usa a figura de são Sebastião na peça são um claro exemplo da minha presença autoral na construção de Meus caros amigos. Esse ícone aparece no espetáculo como parte da cultura popular, principalmente, mas também como elemento que se extrai da cultura letrada, da artística e da religiosa. Como montador desses fragmentos, tive o propósito de criar um espetáculo que, em muitos sentidos, acabasse sendo uma grande colagem: várias representações pictóricas do santo aparecem justapostas para dar forma ao espaço cênico; seu nome é usado para se referir aos indivíduos que fazem parte da experiência homossexual do protagonista e suas características dão forma à pessoalidade e à aparência física deles; o próprio protagonista se apresenta como outro Sebastião, chegando a revelar, na parte final do espetáculo, uma ferida no peito que lembra a que caracteriza a estocada mortal do mártir; fala-se constantemente de pinturas particulares, dos seus autores, das tradições que definem o que culturalmente representa o santo; até uma oração que invoca o seu favor aparece para fechar uma cena. Enfim, só partindo da figura 
de são Sebastião, evidencia-se a colagem como estratégia autoral na criação do espetáculo.

Sobre isso, Rodríguez (2004) diz que o autor pós-moderno é ciente do sentido discursivo do mundo e do caráter parcial e ideológico que lhe dá qualquer discursividade. Por isso, essa atitude se torna antidiscursiva e, em geral, pode seguir duas direções: a ostentação (o autor desmascara a "fraude" própria do seu discurso) e o furto (o autor se dá a liberdade de usar na sua obra elementos de outros autores ou discursos) (Rodríguez, 2004).

Em algum sentido, Meus caros amigos investe na primeira estratégia, uma vez que há um desmascaramento em cena, uma fraude que evidencia certa dualidade do discurso de quem fala. Mas, como estratégia autoral principal usada na criação do espetáculo, segue-se a segunda direção apresentada por Rodríguez. O pesquisador assevera que a direção do furto se concreta na prática intertextual, que oferece a possibilidade de recontextualizar elementos tomados ao fragmentar materiais da cultura (Rodríguez, 2004). Como prática intertextual, a mais evidente foi o uso da oração a são Sebastião (Chagas, 2008). Dentro da ficção, aparece no final de um relato de um encontro erótico entre o protagonista e um jovem que conhece em uma igreja. $\mathrm{O}$ protagonista decide ensinar para o "menino piedoso" a oração do seu padroeiro. Em termos de ação dramática, a invocação verbal do santo se contrasta com uma sequência de ações que reconfigura as intenções iniciais do texto religioso, o qual passa de ser o pedido da proteção e do favor do santo a um convite à experiência erótica.

A direção do furto põe em evidência que não existe originalidade possível na arte pós-moderna. De alguma maneira, ratifica a ideia de que tudo já foi inventado e que o que podemos fazer como autores contemporâneos é encontrar novas formas de apresentar isso que já faz parte de nossa cultura. É um pouco esse exercício de mostrar o já conhecido, mas de outro ponto de vista, fazer visíveis outras realidades a partir do que a própria cultura já tem nos apresentado. A presença autoral radicaria, então, no modo particular como esses materiais são usados para tornar evidente outras visões do mundo.

É isso, pois, o que aconteceu com os materiais provenientes do meu imaginário da homossexualidade. Quando penso na minha 
presença autoral na obra, descubro que, do mesmo modo que não existe um imaginário absolutamente pessoal, não existe uma construção discursiva no espetáculo que não esteja atravessada por uma maneira particular de me apropriar de experiências externas. Era óbvio que a ideia de autor do século XIX, ainda gênio visionário, não atingia os propósitos desta pesquisa. A ideia de autoria, como a de imaginário, descreve-se como apropriação pessoal dos materiais do mundo.

Assim, como autor, coloco-me na função de montador de fragmentos de uma cultura definida por uma construção imaginal própria, que evidencia experiências particularidades de uma pessoalidade que tenta ser levada à cena (o self apresentado por Calvino). Os materiais usados, poderia se dizer, são de domínio público, mas os critérios de seleção e aquilo que com eles se faz são realmente o que definiria as possibilidades autorais do artista.

Uma das afirmações mais significativas de Rodríguez sobre a intertextualidade se refere a que a obra pós-moderna a admite não só como a ação de recorrer a outros textos, mas também como "plagiarismo" e citação irônica, com o interesse de relativizar o processo em si da significação, entendido ele como algo fechado (Rodríguez, 2004). O que se apresenta nessa argumentação é uma ideia de que tudo pode ser feito na construção autoral pós-moderna. $\mathrm{O}$ autor, nessa lógica, reconheceria uma tradição que o precede e, a partir dela, se daria a oportunidade de recontextualizar obras, autores e discursos para ilustrar sua apropriação particular do mundo.

A estratégia intertextual de Meus caros amigos se aproveita dessa circunstância. É assim como se toma muito do discurso do autor francês André Gide para a construção discursiva da peça. Constantemente, o espetáculo brinca com esse assunto. Existe, por exemplo, uma cena completamente inspirada no conto O pombo torcaz (Gide, 2009). A história narrada tem muitas semelhanças com a do relato de André Gide. De todo o espetáculo, é a que mais poderia se aproximar da ideia dramatúrgica de adaptação. Mas, na recepção do público, é uma cena que parece ter um forte caráter autobiográfico. Depois de várias apresentações, têm se aproximado de mim algumas pessoas que querem 
saber mais dessa experiência "minha" na fazenda ${ }^{4}$. O que acontece com essa intertextualidade deliberada, com esse furto à história de Gide, com esse aparente plágio, que causa na plateia uma sensação de confissão, de revelação da mais íntima das experiências reais da vida do ator? Tratase, finalmente, de apropriação particular desse fragmento da cultura. Um outro autor, um outro ator, poderia ter feito alguma coisa completamente oposta. O caráter autoral da peça não está dado pela originalidade das histórias, mas sim pela singularidade do seu tratamento.

$\mathrm{Na}$ cena seguinte, aparece outro tipo de citação importante de Gide. Como parte de uma cena que ficcionaliza a plateia e converte-a nos alunos do protagonista, aparece uma frase que define muito da lógica de pensamento apresentada em Corydon (Gide, 1969): “[n]o dia que alguém estudar as relações existentes entre as artes plásticas e o uranismo, será constatado que seu florescimento coincide com as épocas gloriosas, nas quais a arte se torna mais espontânea e menos artificiosa" (Apêndice B). A frase, obviamente, não é citação literal. O trabalho na cena, além de concentrar um discurso vastamente desenvolvido pelo escritor, modificou-a; no entanto, desde o preciso momento que ela apareceu no ensaio, eu sabia que estava "citando" o depoimento daquele que tanta admiração me causa ${ }^{5}$.

Mas não só a influência de Gide se evidenciou no uso da intertextualidade como estratégia autoral. A frase que fecha o espetáculo nada mais é que a apropriação particular de outro autor, já não literato, mas filósofo, fundamental para esta pesquisa: Gaston Bachelard. A segunda parte de seu belo ensaio Fragmento de um diário do homem fecha com a seguinte frase: "[s]ou apenas uma solidão a ser curada" (Bachelard, 1985, p. 197). Quando estava concluindo o processo criativo, o qual

4 Trata-se de uma cena que narra uma visita à fazenda de um colega de trabalho do protagonista. No meio de uma festa que se dá com a presença dos empregados do lugar, o protagonista se sente atraído pelo jovem filho do motorista do dono da casa. Ambos fogem da reunião e acabam tendo um encontro erótico no quarto de hóspedes. Para mais detalhes, ver a parte 4 do Apêndice B.

5 No segundo capítulo, explica-se mais detalhadamente a defesa do uranismo que aparece em vários textos de André Gide. A influência desse pensamento só se faz evidente tão abertamente na fala do protagonista de Meus caros amigos na cena descrita. 
coincidia com leituras acadêmicas e de outro tipo, descobri-me com essa frase reverberando na minha mente. No meio de um ensaio, entendi que aquelas palavras descreviam perfeitamente o estado no qual se encontrava aquele homem que precisava se confessar para o mundo. Tanto é assim que o espetáculo termina com estas palavras dirigidas à plateia: "[e]u sou uma solidão a ser curada. A consciência de estar só é sempre, na penumbra, a nostalgia de outro. Talvez, no meu caso, seja a nostalgia de muitos" (Apêndice B). Um tempo depois, relendo o ensaio, descobri que também a segunda frase se devia a essa mesma leitura: "[a] consciência de esta só é sempre, na penumbra, a nostalgia de ser dois" (Bachelard, 1985, p. 191).

De novo, não se trata de citação literal, mas de uma espécie de herança. O jogo de palavras conserva muito da lógica de Bachelard; porém, no sentido do espetáculo unipessoal, elas ganham um sentido particular que, de novo, obedecem a essa apropriação particular da leitura do filósofo francês. Permiti-me, como autor, "plagiar" as palavras herdadas de minha experiência leitora.

Pouquíssimas pessoas que, até agora, assistiram ao espetáculo tinham notícias de Bachelard ou de Gide. Mas os leitores desses autores, com certeza, poderão estabelecer relações discursivas entre a proposta cênica e o discurso deles. De fato, insisti em colocar algumas "piscadas" (pistas) para que pudessem reconhecer essas influências. Em uma cena com um estudante, o aluno fala de um ensaio que leu que supostamente é autoria do protagonista do unipessoal. Trata-se do ensaio sobre os cultos frígios, mencionado por Gide em $O$ imoralista (1972). O protagonista responde: “[e]sse texto não é meu, é do meu pai” (Apêndice B). A brincadeira tem o objetivo de evidenciar a citação e reconhecer a influência de uma tradição poética particular, mas a estratégia, tratando-se de um experimento artístico, fica criptografada só para alguns, liberada das exigências que outros contextos têm nesse sentido (fica aqui a página para o leitor pesquisador interessado na corroboração do dado: p. 11$)^{6}$.

6 Em notas de imprensa e em material de divulgação de Meus caros amigos, anuncia-se o espetáculo da seguinte maneira: "[i]nspirado no discurso do autor francês André Gide (O imoralista, Corydon: tratado do homossexualismo 
A intertextualidade de Meus caros amigos é uma estratégia autoral que corrobora a existência de uma pessoalidade particular (a minha, a do ator). No caso mencionado no parágrafo anterior, tem essa condição de citação irônica; mas, em alguns momentos, aparece como plagiarismo (o feito com Bachelard, por exemplo). Em outras ocasiões, as referências são liberadas para evidenciar a origem da intertextualidade proposta. É o que acontece quando, em uma cena em que se assinala uma das pinturas, se delata o nome do seu autor (Agnolo Bronzino) ou quando, em outra, se pergunta diretamente para a plateia se esta conhece o nome do autor do quadro de Giovanni Bazzi, "Il Sodoma" (até agora nenhum espectador soube dizer o nome), acabando por revelá-lo.

As estratégias autorais apresentadas aqui demonstram a maneira que encontrei como ator de colocar meu próprio dizer na cena a partir da minha experiência. Os materiais do meu imaginário sobre a homossexualidade se alternaram com alguns eventos que também fazem parte de mim, expressos em vivências e lembranças. Além disso, a criatividade despertada pelo próprio processo de encenação permitiu a aparição de pequenas ficções não desprendidas desses materiais concretos nem da experiência autobiográfica e de alguns depoimentos ou pontos de vista sobre assuntos não diretamente relacionados com a homossexualidade e que foram aparecendo sem nenhum tipo de planejamento.

Até o momento, fala-se do que apareceu como estratégias autorais conscientes. Na continuação, será falado de autoria no sentido daquilo que não foi precisamente produto do planejado.

\section{Perda do controle e autoria compartilhada em Meus caros amigos}

Entender que a busca pela categoria autor não se achava na reivindicação da propriedade absoluta do discurso tornou possível entender

e O pombo torcaz) e alimentado por múltiplas referências plásticas e da experiência própria do ator, a peça reflete sobre a falsa moral de uma sociedade que 'aceita' a homossexualidade contanto que ela não seja desvelada." 
parte da construção autoral da cena como exercício compartilhado entre meu eu ator-autor e os espectadores. Todas aquelas estratégias autorais que conscientemente desenvolvi na consolidação do espetáculo unipessoal garantiram o surgimento da forma, mas, quando ela foi apresentada para diferentes públicos, experimentei novas perdas do controle sobre a obra.

Como já foi apresentado, existia a estratégia consciente de deixar vazios a serem preenchidos pelos espectadores, mas sobre o que não se colocou desse modo, achava-se que existia unanimidade entre o que como emissor do discurso enunciava e o que a plateia atingia. Não passou muito tempo para perceber a ingenuidade dessa consideração. Na mesma estreia, por exemplo, encontrei-me com a presença de uma ficção paralela que nada tinha a ver com os propósitos iniciais do processo criativo.

No capítulo anterior, ficou claro que uma das poucas clarezas existentes na hora de começar o processo criativo era o interesse pela construção de uma ficção, pela narração de uma história que revelasse o universo que queria apresentar. Meus caros amigos, assim, mostra a história de vida de um homem casado com uma mulher, filho de um professor universitário, herdeiro de uma condição econômica favorável, também membro do mundo acadêmico, vítima de uma doença grave que fez com que mudasse o sentido da sua vida, posteriormente aberto à experiência homoerótica, imigrante e finalmente viúvo. Nunca se deu um nome para o protagonista, até porque não existia essa necessidade, partindo da lógica de ficção proposta.

Mas grande parte da plateia parece que sim deu para ele um nome: o do ator-autor do espetáculo. Depois da estreia, um grupo de atrizes da Escola de Teatro da Universidade Federal da Bahia, com as quais tinha trabalhado como assistente de direção no espetáculo Bonitinha, mas ordinária (2012), sob a direção de Luiz Marfuz, entraram no camarim com uma estranha expressão de consternação. Alguma delas se aproximou de mim e falou: “[o]h, Juan, eu não sabia”. Não sabia o quê? Compreendi depois de esclarecer o assunto que grande parte da plateia acreditava ter assistido a um espetáculo autobiográfico.

A sensação continuou sendo uma constante durante toda a temporada. Cada noite, algum espectador se aproximava para perguntar 
se se tratava de um relato desse tipo. $\mathrm{O}$ mais surpreendente para mim era que, muitas vezes, se tratava de algum conhecido. O que havia no espetáculo que criava essa ficção autobiográfica? É verdade que no processo criativo eu usei parte de minha experiência pessoal, mas nada do autobiográfico ganhou na peça um lugar preponderante. Alguma situação vivida desenvolveu uma das cenas ou deu um matiz particular em outra, mas nada do narrado poderia ser corroborado como um evento da vida do autor. De fato, muitos dos espectadores queriam saber mais do adolescente da fazenda (o da cena inspirada em $O$ pombo torcaz). Como era que a cena que menos tinha de experiência pessoal era vista como a mais confidencial das confissões?

Sem a existência real de uma narração baseada completamente na minha própria experiência vital, nem de uma intenção de criar essa ideia no público, como essa sensação de relato autobiográfico aparece? Seria possível que o uso dos elementos da minha narrativa pessoal tivesse produzido algum tipo de confusão em relação aos mecanismos determinados para a transmissão da ficção? Deveria reconsiderar o apresentado e modificar aquilo que pudesse criar essa particular recepção do espetáculo? Definitivamente, não. Finalmente, a aparição dessa ficção autobiográfica acabava sendo muito mais efetiva na hora de tratar a temática que desde o início queria apresentar. O público se conectava com uma experiência que lhe parecia mais "real", menos longínqua. Tentar ir contra essa leitura, “corrigir” essa perda de autoridade sobre o apresentado seria, simplesmente, retroceder na lógica de autoria que eu mesmo tinha projetado.

O que se gerou com o surgimento da nova ficção foi a compreensão latente do que significa o exercício de autoria compartilhada. Foi realmente vivenciar o que entendia por dupla produtividade. A partir de elementos dados pela encenação, o público criava uma nova ficção que, sem ignorar a proposta, a superava. $\mathrm{O}$ fato de considerar o relato biográfico cobria a ficção de uma espécie de transcendência, fazia da enunciação uma instância viva que não ficava só no terreno do emissor, mas também que ganhava força na experiência da recepção.

Experimentei minha própria morte como autor no dia em que me inaugurava como tal. A prática artística tem a faculdade de dar vida àquilo que na teoria nem sempre consegue ter sentido. Foi o que 
aconteceu com essa perda de controle sobre a ficção proposta e o indicado por Barthes:

[...] um texto é feito de escritas múltiplas, saídas de várias culturas e que entram umas com as outras em diálogo, em paródia, em contestação; mas há um lugar em que essa multiplicidade se reúne, e esse lugar não é o autor, como se tem dito até aqui, é o leitor: o leitor é o espaço exato em que se inscrevem, sem que nenhuma se perca, todas as citações de que uma escrita é feita; a unidade de um texto não está na sua origem, mas no seu destino, mas este destino já não pode ser pessoal: o leitor é um homem sem história, sem biografia, sem psicologia; é apenas esse alguém que tem reunidos num mesmo campo todos os traços que constituem o escrito. (2004, p. 5, itálico no original)

$\mathrm{Na}$ citação anterior, Barthes resume muito do que define os mecanismos da criação de Meus caros amigos. O conceito de multiplicidade para descrever as qualidades do texto (já sabemos que a palavra no contexto desta pesquisa supera a acepção dada à produção escrita) evidencia o princípio criativo que envolveu todo o processo. Torna-se relevante ver como a palavra que ajuda a definir a morte do autor para Barthes constitui o ponto de partida para a busca dessa categoria nesta pesquisa. De alguma maneira, é como se eu estivesse matando meu eu autor antes de poder instaurá-lo. Agora compreendo que o conceito de autoria que procurava tinha que ser encontrado não na individualização das minhas ideias, nem na exaltação dessa individualidade, mas no reconhecimento de uma série de "escritas múltiplas" que me atravessam e na forma particular de colocá-las no palco para, dessa forma, coletivizar minha singularidade.

Mas, voltando à última citação de Barthes, é interessante como ele coloca esse encontro de escritas múltiplas no leitor (no nosso caso, falaremos de espectador), e não mais no autor. Se for na figura do espectador em que se encontram todas as citações que conformam o espetáculo, toda aquela intertextualidade que defini como estratégia autoral, torna lógica a aparição de uma nova ficção, já no próprio universo da plateia. O destino de todos esses fragmentos da cultura 
que, de maneira pessoal, juntei para a conformação de um espetáculo encontrariam outras formas na experiência com o público. E foi ele que, liberado de todas as justificativas pessoais, criou uma ficção paralela, autobiográfica, sobre a qual eu já não tinha autoridade nenhuma.

Quais dos elementos da encenação contribuíram à formação dessa ficção autobiográfica paralela? Essa resposta poderia se encontrar na observação dos traços mais comuns do que entenderíamos por teatro autobiográfico. Martha Ribeiro (2006) diz que, na realização dos espetáculos autobiográficos, "[a]tor e autor se confundem com a identidade do eu espetacular” (p. 39). Isso começaria a dar sentido à associação, dado que sempre existiu o propósito de não separar a figura do ator da do autor, o que se expressou de múltiplas formas nos procedimentos descritos neste livro. Evidentemente, a forma obtida pelo unipessoal permitiu essa fusão, o que acabou se traduzindo em um olhar particular da plateia. Falando do que nomeia como Novo Teatro ${ }^{7}$, no qual reconhece uma explosão do espaço autobiográfico, a pesquisadora assinala que:

[...] ator e personagem se mesclam em uma espécie de presença que torna o personagem tão real quanto o primeiro. $\mathrm{O}$ ator, dentro deste processo de criação, cria uma alteridade (personagem) tão forte e "real" que atinge (por contágio) de modo profundo o público. A distinção entre vida e ficção fica muito tênue, o espectador acaba por vivenciar uma possível identidade entre o criador e a criatura. Aquilo que é (o ator no palco vivendo uma situação fictícia) se aproxima muito daquilo que poderia ser (o ator vivendo uma situação real em tempo real). No palco o jogo do ator é ambíguo, o que torna difícil para o espectador separar a ficção da realidade. (Ribeiro, 2006, p. 40)

7 Trata-se do termo proposto por Marco de Marinis para nomear um conjunto de experiências e propostas teatrais que surgiram nos Estados Unidos e na Europa entre 1947 e 1970 em oposição ao teatro oficial, dando como exemplos dele fenômenos como o happening e os espetáculos do Living Teatro (Ribeiro, 2006). 
É relevante observar como o depoimento de Ribeiro pode explicar o que acontece em Meus caros amigos, sem pertencer nem acolher pressupostos de tradições parecidas ou relacionadas com o Novo Teatro. Mas, efetivamente, a sensação que o público expressa depois das apresentações é a de ter assistido a uma experiência real. Claro, no caso desse unipessoal, a situação fictícia se aproxima muito do que poderia ser uma situação real do ator, até porque apresenta "realidades" que tocam profundamente seu ser. Além disso, no processo criativo, renunciou-se à ideia de caracterizar uma personagem que, em aparência e caráter, fosse muito distante da realidade do ator-autor.

O leitor terá percebido que, quando se fala do homem da ficção proposta em Meus caros amigos, evita-se o uso da palavra persona$\mathrm{gem}^{8}$. Sempre, neste livro, faz-se referência a ele como "o homem" ou “o protagonista” do espetáculo. Isso se deve a que, no interesse de deixar o estágio da interpretação, como ator, decidi que não investiria na caracterização de uma personagem, noção que, em muitos contextos, entende-se como sinônimo de interpretação (bons intérpretes seriam aqueles atores que conseguem grandes caracterizações).

De maneira nenhuma estou afirmando que a caracterização tenha que ser desterrada do palco para quem tenta fugir do ato interpretativo. Seria desconhecer uma das mais importantes ferramentas de trabalho do ator. Mas, na busca particular do meu eu ator-autor, eu queria fugir de uma tradição que entende a caracterização como a ação de “[e]xpressar aquilo que não se é. Dar forma expressiva ao que não se obtém com a via da identificação" (Eines, 1997b, p. 67). Segundo Jorge Eines (1997b), a caracterização marca as diferenças entre o indivíduo ator e o papel, entre as formas expressivas do ator em seu comportamento cotidiano e as das personagens em sua conduta cênica.

8 Essa escolha tem uma estreita relação com o reconhecimento do que Jean-Pierre Sarrazac (2012) estuda como crise do drama. Nesse panorama, detecta-se um enfraquecimento da figura da personagem, o qual acaba sendo, ao mesmo tempo, causa e consequência da crise do drama (Ryngaert, 2012). Esse enfraquecimento, do meu ponto de vista, pode se perceber claramente na dramaturgia contemporânea, mas nem tanto na prática do ofício do ator e nas técnicas interpretativas tradicionais. 
Com o interesse de me concentrar mais na exposição de um dizer próprio, deixei de lado a ideia de caracterizar uma personagem. Se o que procurava era a construção de um espaço poético próprio, preferia me centralizar na consolidação de um discurso, e não investir na proeza da técnica interpretativa para criar uma aparência possivelmente diferente da minha, o que, caso obtivesse um bom resultado, concentraria a atenção da plateia na forma do emissor, e não no discurso que tentava apresentar.

Diz Jean-Pierre Ryngaert (2012) que "[c]onferir identidade ao personagem significa fazê-lo preexistir tanto ao texto como ao palco" (p. 136). Esse nunca foi um interesse do processo criativo. Meu propósito principal ao não dar nome para o protagonista era afiançar o presente da ação cênica, era criar um espaço de comunhão entre o público e o ator sem criar distâncias, sem apresentações formais. Também não quis dar para ele características físicas particulares ou, pelos menos, diferenciadas das minhas. Não queria "distrações" no ato discursivo. Como ator intérprete, sempre recebi com agrado as críticas em relação às minhas capacidades histriónicas, principalmente porque nelas se concentrava minha contribuição para a encenação. Com Meus caros amigos, nunca pretendi chamar a atenção da crítica ou do público quanto a isso. Claro, essa escolha acabou despertando outras conclusões na imaginação dos espectadores, o que, dito mais uma vez, não fazia parte do meu planejamento.

O espaço que deixou tal ausência de caracterização foi preenchido na imaginação dos espectadores pela ficção autobiográfica. Registrava-se, assim, o jogo ambíguo do ator. Essa ambiguidade entre o ser humano real e o da ficção se representa também em algumas escolhas estéticas do espetáculo e no uso dos materiais criativos. Um importante exemplo disso é o uso de fotografias para apoiar a narração. Como foi apresentado no segundo capítulo, elementos como estes foram usados no processo como material criativo. Para contribuir com a sensação de culpa que a morte da esposa gera no protagonista, realiza-se, no final do espetáculo, um ritual de despedida no qual ele queima fotografias que supostamente ele está em companhia da mulher. Para isso, manipulei fotografias pessoais, as quais intervim adicionando sombras que representavam a mulher. O público, 
ignorando o deliberado apagamento da figura feminina inexistente, deu um sentido documentário para esses objetos (Figura 13) ${ }^{9}$.

Figura 13. Meus caros amigos. Estreia em espanhol: $18 \mathrm{de}$ fevereiro de 2014. Pequeño Teatro de Medellín (Colômbia).

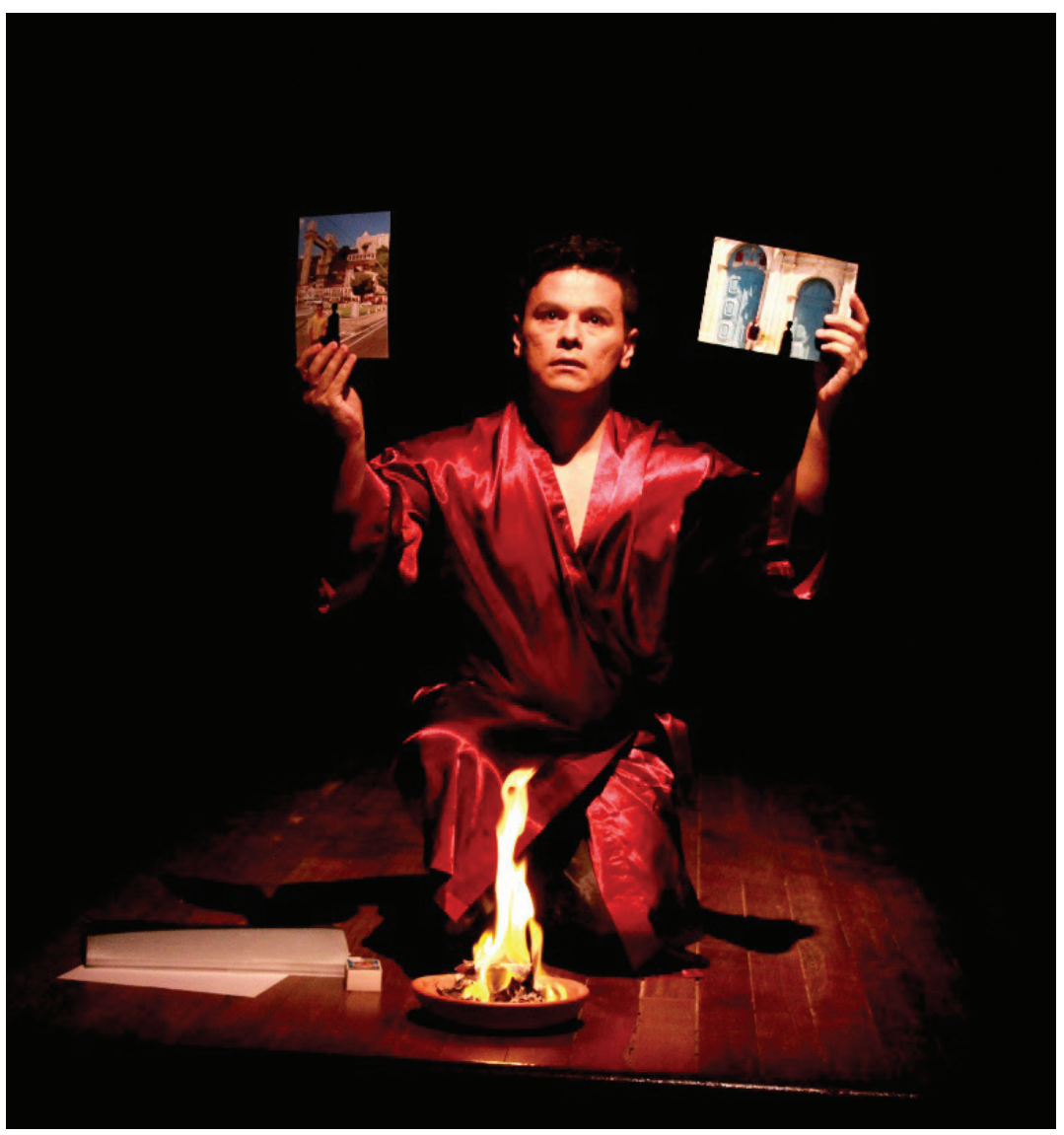

Fotografia: Germán Guevara.

O uso desse tipo de estratégias narrativas é muito comum no teatro autobiográfico. Isso porque elas contribuem na aparição do "real” em

9 Torna-se relevante ver como a forma em que a ideia foi apresentada cenicamente não comprometeu a verossimilhança da ficção. Pelo contrário, o que seria oposto ao corroborável - a manipulação do documento- parece ter aumentado o efeito autobiográfico. 
cena. Embora essa não tenha sido a intenção do uso de fotografias em Meus caros amigos, não se pode ignorar a força dessas imagens no palco. Sobre o assunto, a pesquisadora Gabriela Lírio Gurgel Monteiro (2011) assinala, em um artigo que estuda o uso de imagens no teatro autobiográfico, que:

[a]o utilizar imagens projetadas, fotos, vídeos, slides, imagens de computadores, trechos de filmes, reprodução de espaços de intimidade, entrevistas, a vida como produto da narração vê-se transformada em espetáculo imagético, em "efeito cinema”. Um efeito [...] que no espaço do teatro [...] modifica a percepção do espectador, ampliando as possibilidades de interação à obra apresentada. (p. 118)

Agora entendo que foi esse jogo ambíguo entre a vida do autor - representada em suas inquietações particulares postas em cena-e a presença de um ser ficcional — desprovido de uma caracterização que o distancie evidentemente de seu criador- o principal motivo dessa sensação, da forma autobiográfica que adquiriu o espetáculo. Mas existe realmente essa forma autobiográfica? Ribeiro (2006) assevera que existe, sim, mesmo quando não se trata de um espetáculo mais próximo do documentário.

Podemos dizer que uma autobiografia pode mentir, assim como uma "forma autobiográfica" pode revestir uma escrita ficcional, explorando assim a possibilidade de narrar em primeira pessoa uma história puramente imaginada. [...] a obra teatral pode-se revestir de uma forma autobiográfica, e fazer da encenação algo que trate da própria vida de seus fazedores. (p. 40)

Aparecem aqui novas pistas da forma autobiográfica de Meus caros amigos. O uso da primeira pessoa é uma delas. Mas isso não se expressa só no uso gramatical, mas também no propósito de a obra ter partido de inquietações que efetivamente fazem parte da vida do seu fazedor. É claro que a(s) história(s) de Meus caros amigos não narra(m) eventos corroboráveis da biografia do seu criador, mas sim suas visões 
de mundo. Partindo só do tema principal explorado, a experiência homossexual do protagonista do espetáculo é muito diferente da minha, mas é óbvio que as perguntas que ele se faz são muito próximas das que eu mesmo me fiz ou faço. Isso faz com que a abordagem unipessoal da criação contribua para a aparição da forma autobiográfica.

É importante considerar, nessa ordem de ideias, que fazer da encenação algo que trate da vida do seu fazedor se traduziu em Meus caros amigos no surgimento de outros temas não contemplados no início da criação. Um deles é o tema do exílio. Quando comecei o processo (assim se colocou no capítulo anterior), o desafio de criar um espetáculo em uma língua que não era a minha definiu uma maneira particular de apropriação da palavra como elemento cênico. Isso não só transformou o exercício formal do espetáculo, mas também o de seu conteúdo. Era difícil expressar em português algumas considerações que queria levar ao palco. Imerso na ficção, apropriei-me dessa circunstância e tirei proveito dela.

Em um dos momentos mais "confessionais" do homem em cena, a dificuldade de expressar seus sentimentos faz com que renuncie a continuar falando em português e retome sua língua materna: "[h]ay dolores que solo pueden expresarse en la propia lengua... Ninguna palabra en portugués será suficiente para calmar esta culpa..." (Apêndice B). E, depois de uma pausa, conclui: “[é] tão difícil expressar a dor numa língua que não é a minha” (Apêndice B). Essa foi a primeira aparição no processo criativo do tema do exílio, assunto que me interessa não só pela minha própria experiência como imigrante no Brasil, mas também porque foi o tema da minha dissertação de mestrado em Literatura. Nesse panorama, o português acaba sendo o que Imre Kertész (2007) chama de "língua hóspede", isto é, o uso por parte de um autor da língua do país de chegada para, a partir da linguagem em si, entender a condição de exilado ${ }^{10}$.

É evidente que a inquietação pelo tema não se esgotou na pesquisa desenvolvida no mestrado e que continuava sendo parte das minhas

10 Um exemplo citado por Georges Banu, para o caso do ator exilado, poderia se homologar ao proposto por Kertész para o caso do escritor. Falando sobre a participação do ator chileno Andrés Pérez Arroyo no espetáculo Sihanouck 
inquietações fundamentais. Sobre o momento resenhado, o crítico soteropolitano Uendel de Oliveira Silva (2013) publicou o seguinte:

[o]s momentos em que o ator alcança as nuances e desnuda o seu íntimo misturado ao do personagem, são aqueles em que a cena cresce e toca - por exemplo, quando o personagem fala da dificuldade em expressar numa língua estranha as suas dores mais recônditas, num momento em que a vida do ator parece costurar-se à do personagem mais explicitamente. (s/p.)

Pode-se perceber, na fala do crítico, como esse momento mostra a forma autobiográfica do espetáculo. Evidentemente, trata-se de um momento no qual o eu autor sobressai e se impõe como realidade da cena. Isso acontecerá em diversos momentos, nos quais aparecem frases como: “[...] a rua, esse lugar de todos que só começou a ser meu quando experimentei a condição de estrangeiro" (Apêndice B).

A exposição do tema do exílio, que não fazia parte dos pressupostos criativos do espetáculo, representa essa condição do eu autor que quer sair, inclusive, interrompendo o discurso "principal" da obra, o que, novamente, contribui para a percepção de uma forma autobiográfica da peça. Assim o ratificam as impressões do mencionado crítico. "O tom confessional permite que o artista transite entre sua própria obra e a do personagem, borrando os limites que as separam — o próprio Juan David é um estrangeiro num país de língua diferente da sua” (Oliveira, 2013, s/p.). Como anota o Theodor W. Adorno, aquele que já não tem pátria acaba encontrando no escrever (eu ampliaria a expressão a "no criar") seu lugar de residência (citado por Said, 2005). Meus caros amigos foi, nessa medida, refúgio e lar, lugar de encontro, enfim, espaço poético de construção do eu.

A condição de imigrante do ator-autor do espetáculo, colocada também no protagonista da ficção proposta, contribuiu, em grande

de Ariane Mnounchkine, aponta: “[a] confrontação com a língua aparece assim como uma imagem da condição do ator, de seu exílio, na maioria das vezes involuntário. O ator que vem de longe, o ator das origens longínquas” (Banu, 2011, p. 393). 
medida, à forma autobiográfica do espetáculo. O crítico assim parece concluí-lo. Para o público, um elemento que também modificou o fazer do artista se tornou fundamental para a consolidação dessa percepção: o uso da palavra. Georges Banu (2011) assevera que "[a] percepção da relação do ator estrangeiro com a língua não se produz de maneira indiferente" (p. 394). Aconteceu isso com Meus caros amigos. O evidente sotaque estrangeiro e os giros dados à língua falada por um "gringo" em cena contagiaram a plateia de um sentido de verdade que dava à cena uma aparência mais genuína: “[...] o sotaque estrangeiro engendra reações ligadas ao efeito que suscita em cena, esse lugar da Nação, a presença de outra Nação" (Banu, 2011, p. 392).

Mas o que aconteceu com a forma autobiográfica do espetáculo quando esse sotaque estrangeiro sumiu da cena? Estou me referindo à versão em espanhol da obra que se estreou em 2014 na Colômbia. Para começar a responder a essa questão, é importante partir do fato de que a tradução da obra representou uma nova perda de controle sobre ela. Fazer Meus caros amigos em espanhol e no meu próprio país foi um desafio. Como parte do que representa esse projeto autoral, era muito importante apresentar o trabalho no meu próprio país e no contexto teatral do qual tinha feito parte durante toda a minha carreira. Além disso, tratava-se de me posicionar de uma maneira diferente diante de um público que já me conhecia como parte de vários coletivos teatrais.

O processo de "tradução" do espetáculo foi bastante difícil. Foi uma situação surpreendente, dado que achava que fazer a peça na minha própria língua seria mais fácil do que fazê-la em português. Grande engano. Para começar, a tradução da linguagem falada quebrou com todo o ritmo do espetáculo. Encontrei-me com uma língua dura, de sons fortes e expressões pesadas. Isso fez com que a relação corpo, espaço e voz se modificasse de maneira notável. Como ator, enfrentava-me quase com um material novo. As ações precisavam se adaptar à nova situação, e o corpo sofria inesperadas transformações.

A própria ficção proposta por mim sofreu também várias transformações. O que no Brasil era a confissão de um homem que abandonou seu país para, em novas geografias, libertar-se e encontrar seu verdadeiro ser se converteu, na Colômbia, na expressão do homem que volta para 
reconhecer, diante de seus conterrâneos, as inúmeras transformações que algumas circunstâncias da sua vida e da sua passagem pelo "calor tropical brasileiro" suscitaram na sua existência.

Tudo isso fez com que Meus caros amigos na versão em espanhol acabasse por se transformar em outra obra. De novo, confrontava-me com minha morte como autor. Perdia a autoridade sobre o espetáculo e tinha que me render ao que as novas circunstâncias exigiam. $\mathrm{O}$ novo contexto me impedia continuar com a ficção inicial e exigia-me uma nova disposição corporal, um novo jogo cênico. Além disso, aqueles momentos nos quais a voz autoral se sobrepunha à narração feita pelo protagonista ganharam novas qualidades.

O tema do exílio, por exemplo, que inicialmente pensei que perderia importância na volta ao meu país, ao contrário, acabou se posicionando de maneira mais concreta. Na versão do texto dramatúrgico em espanhol (Apêndice C), pode se observar como, por exemplo, a palavra exilado aparece literalmente na fala do homem, o que nunca se deu na versão em português. Além disso, as reflexões sobre a língua hóspede sofreram variações no caminho de volta à língua materna e acabaram ganhando um lugar mais preponderante, justificando inclusive o retorno do protagonista a seu país.

Durante mis últimos días en Brasil, el silencio fue mi único amigo porque hay dolores que solo pueden expresarse en la propia lengua... Ninguna palabra en portugués era capaz de calmar mi culpa. Era tan difícil expresar el dolor en una lengua que no era la mía. Pensaba que no tenía otra cosa que la palabra para tentar calmar mi espíritu desesperado. Por eso estoy de vuelta. (Apêndice C)

De novo, criador e criatura se fundiam em uma só entidade. Na versão em espanhol, a necessidade existencial do protagonista coincidia com a necessidade estética do ator-autor do espetáculo. Para ambos, a língua acabava sendo metáfora dessa situação. Foi aí que entendi que a forma autobiográfica do espetáculo não se reduzia à aparição de um sotaque particular, ao uso gramatical da primeira pessoa do singular ou à exposição do corpo do ator que renuncia a qualquer 
tipo de caracterização. Devia-se, principalmente, à abordagem unipessoal da criação.

Paradoxalmente, essa abordagem unipessoal do ato criativo deu também um particular tipo de autonomia à obra em si. Ela acaba tendo uma vida própria e seu autor perde autoridade enquanto ela vai se afiançando como objeto estético. Isso explica a impossibilidade da tradução de alguns momentos característicos da peça. A oração a são Sebastião é amostra particular desse assunto. Houve uma resistência do corpo a aceitar uma versão em espanhol da oração. A apropriação particular que fiz dela na criação do espetáculo impossibilitou que fosse transposta à língua espanhola, talvez devido à construção gramatical do texto, muito afastado da linguagem falada e do meu próprio uso do português. Igualmente, como pode se observar no Apêndice $\mathrm{C}$, foi impossível falar de mis queridos amigos, o que seria a tradução literal do título do espetáculo, não só porque o sentido da expressão muda notavelmente de uma língua para a outra, mas também pelo que representou chegar a essa curta frase para abranger tudo aquilo que coloquei na obra. Nunca foram meus queridos amigos, sempre foram os meus caros.

A abordagem unipessoal da palavra na criação do espetáculo também fez com que a tradução fosse uma luta constante. Uma das circunstâncias que mais me surpreendeu foi a dificuldade de incorporar à encenação minha própria língua. Sempre houve, nas apresentações em espanhol, várias palavras que se negaram a ser traduzidas, vários giros gramaticais que se resistiram à mudança de língua. Isso criou uma nova sensação na plateia que, de novo, ficou fora do meu controle autoral. Na participação no Terceiro Festival de Teatro Rosa de Bogotá, no qual o espetáculo ganhou o prêmio de melhor dramaturgia, depois da segunda apresentação, o ator equatoriano Jorge Mateus, que também apresentava um unipessoal no festival, falou sobre a sensação estranha de ter assistido a um espetáculo em espanhol feito por um colombiano que parecia mais cômodo na língua portuguesa (o que se evidenciava na cena da oração) do que na espanhola, como se se tratasse de um exilado na sua própria pátria.

O depoimento do equatoriano fez com que essa resistência do próprio espetáculo à tradução absoluta da peça ganhasse sentido e explicou o que já tinha percebido na temporada de estreia em espanhol, uns meses 
atrás. Vários dos espectadores, além de perguntar pelo autobiográfico, perguntaram pela minha nacionalidade. É impressionante o poder que a obra tem sobre seu criador. Ela, evidentemente, tem maior autoridade sobre seu autor do que o último sobre a primeira.

A experiência de Meus caros amigos revelou, assim, uma busca pela autoria da cena, mas demonstrou que ela não se expressaria contundentemente na afirmação de uma individualidade radical ou de um discurso absolutamente autônomo. Pelo contrário, constatou que se podia, sim, criar um espetáculo no qual o ator não fosse o meio de transmissão de uma mensagem, mas seu próprio emissor, e que, portanto, pudesse colocar no palco suas inquietações particulares a partir da exposição de sua pessoalidade criativa para possibilitar a aparição de uma obra proposta por ele e completada pela experiência da recepção.

\section{Assinatura de um processo criativo}

Como foi apontado no começo deste capítulo, a busca pela categoria autor neste processo de criação começou no exercício cênico, mas acabou se disseminando a outros contextos. A construção do espetáculo unipessoal só representava uma parte —muito importante, claro- do projeto autoral que se iniciava com Meus caros amigos. Em termos de Juan Manuel Zapata (2011), esse exercício correspondia à parte do enunciado, mas, para consolidar a "encenação" dele, teria que empreender outro tipo de ações. É interessante como Zapata usa o termo encenação para determinar as ações e as situações de enunciação dos discursos autorais como manifestações de uma posição particular no campo artístico. Nesse panorama, já tendo definida minha presença autoral no conteúdo discursivo do espetáculo (o que Zapata define como plano textual), só restava me posicionar como tal no meio artístico teatral (o que corresponderia ao plano comportamental). A respeito, diz Zapata (2011): 
[a]s representações que nós fazemos de um autor ou de um artista, representações que definem nossos posicionamentos diante do que chamamos de literário ou de artístico, têm sido construídas e mediatizadas tanto pelas instâncias de produção quanto pelas instâncias de difusão e circulação do campo. (p. 53, tradução minha)

Nas palavras do pesquisador, evidencia-se que a construção da categoria autor (ou da de artista) não depende exclusivamente de sua produção discursiva, mas também das ações que o definem assim no meio ao qual pertence e das que acompanham as particularidades de seus processos de circulação nesse mesmo meio. É por isso que, na experiência de Meus caros amigos, não foi suficiente produzir um espetáculo sem intervenção criativa de outras figuras, como um diretor ou um dramaturgo, para atingir o objetivo, mas empreender várias ações cujo interesse principal fosse a consolidação do ator do espetáculo como autor da obra.

Por esse motivo, definiu-se como estratégia principal a ação da assinatura, estratégia muito comum nas artes plásticas e na literatura. Inclusive no teatro, a prática da assinatura é muito comum, mas como atribuição particular de dramaturgos (devido à tradição literária, como se descreve no primeiro capítulo) ou de encenadores. No caso deste processo criativo, a assinatura apareceu como uma necessidade de, por um lado, quebrar com essa tradição e, por outro, de reivindicar para si a função autor como sujeito da enunciação.

A propósito da função autor, é importante lembrar os locais nos quais Foucault (2001) determina o exercício dela: no nome, na apropriação, na atribuição e na posição. Como foi assinalado no primeiro capítulo, esses locais representam diferentes tipos de impossibilidades: a de reduzir a autoria da obra a um nome próprio, a de considerar o indivíduo proprietário único do enunciado, a de atribuir o dito ou o escrito a uma entidade absolutamente fechada e a de determinar o espaço físico ou virtual que ocupa o autor em uma produção discursiva ou em um campo de conhecimento. No reconhecimento dessas impossibilidades, toma corpo a ideia da morte do autor. Mas, como já Foucault o descreveu, isso não faz com que a função autor desapareça. 
É isso o que retoma Juan Manuel Zapata (2011) para falar da ressurreição do autor como entidade sociológica e de projeto autoral como experiência que possibilitaria o reconhecimento da função autor em nossos dias. Nesse sentido, o encontro com a autoria não acabava com a consolidação de Meus caros amigos como obra artística. Ao contrário, apenas começava. O primeiro desafio era me assumir como sujeito da enunciação para a comunidade teatral. Para isso, a única opção era reconhecer publicamente a autoria do espetáculo. Por essa razão, começou a se divulgar o espetáculo com uma ficha artística bastante pequena —na qual existia um único crédito-, como se pode observar no cartaz do espetáculo (Figura 14).

Sob o design do artista plástico colombiano Fredy Alzate, o cartaz se converteu na primeira imagem de divulgação do espetáculo e na primeira estratégia fora da cena para a consolidação de um eu autoral. A partir de uma pintura criada por Alzate, baseada em uma das imagens do espetáculo, o cartaz coloca como figura central o sujeito enunciador do discurso que, para efeitos práticos, pode ser tanto o ator quanto o protagonista da ficção. Como único crédito artístico, destaca-se a função criadora, sem especificações relacionadas com as habituais funções teatrais: dramaturgia, encenação, interpretação ou atuação. Isso foi colocado de maneira deliberada para entender o ato criativo total como uma elaboração discursiva que não separa o uso da palavra, da ação dramática e das outras linguagens cênicas que intervêm na consolidação do espetáculo teatral. Esse gesto constitui o que nomeio aqui como a assinatura do processo criativo. Como ator emancipado das outras funções teatrais, atribuo-me o crédito de agente criador do espetáculo e assino a obra com meu nome próprio: Juan David González Betancur. 
Figura 14. Cartaz Meus caros amigos

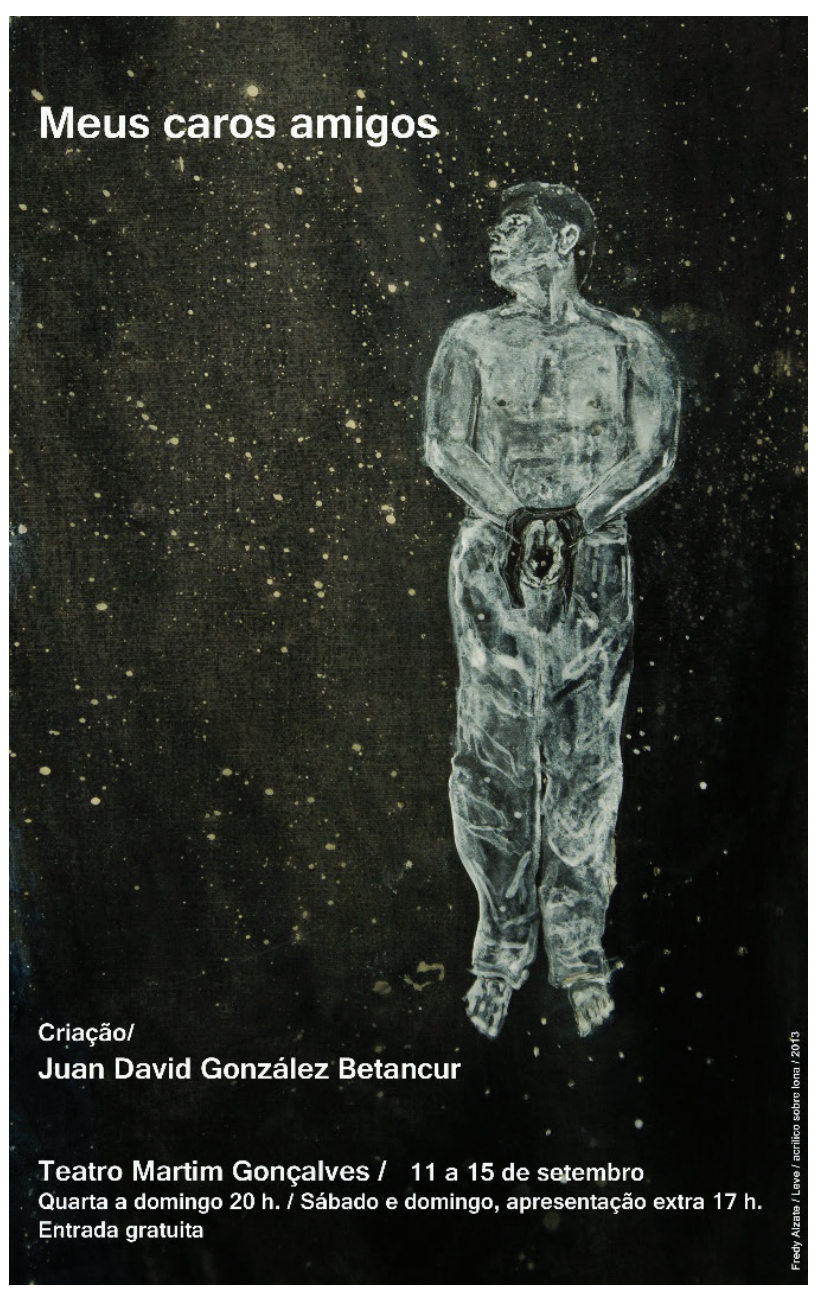

Pintura e design: Fredy Alzate.

De acordo com os interesses desta pesquisa e com as conclusões que me levaram a não separar o processo nas etapas tradicionais da prática teatral que conhecia, não me coloco como dramaturgo, encenador e ator do espetáculo, mas como seu próprio criador, na tentativa de começar a divulgar, também dentro do público, a ideia de que o ator pode, sim, ser autor de sua própria obra. Por que teria que se separar o que no processo criativo funcionou como um todo integrado? Chegar à palavra criação e colocá-la no cartaz como único crédito artístico constituiu um ato de 
assinatura deliberada e representou o ponto de partida de uma busca pela consolidação do meu eu autor no campo artístico ${ }^{11}$. Foi, assim, a primeira das estratégias no campo comportamental do projeto autoral.

Em algum momento, considerou-se que se poderia usar a palavra autoria nessa sucinta ficha artística; contudo, levando em consideração que a palavra autor está diretamente relacionada à de dramaturgo na tradição teatral, seu uso poderia instaurar ambiguidades que não me interessava manter, como o fato de relacionar o termo, novamente, com a escrita de um texto dramatúrgico que antecedesse a encenação. Além disso, embora seja considerado por muitos um conceito redundante, o termo ator-criador de Odete Aslan (1979) está intimamente relacionado com o ato emancipador que distinguiu as particularidades desta pesquisa. Em um dos sentidos propostos pela pesquisadora, criação, no contexto do trabalho do ator, representaria o desejo de produzir um objeto artístico concreto, estabelecendo uma relação de sinonímia entre as palavras criador e artista. Nessa ordem de ideias, criador estaria mais próximo de autor na acepção que esta pesquisa dá à categoria. Finalmente, entende-se por autor o "[c]riador da obra artística, literária ou científica” (Ferreira, 2010, p. 81). Outro dos motivos para assinar como criador do espetáculo radica no uso constante do termo para definir experiências nas quais o trabalho do ator se afasta da interpretação ou para falar do grau de autonomia na sua função criativa (Carreira e Oliveira, 2006-2007).

Assim, pois, Meus caros amigos acaba se posicionando como uma obra artística com uma assinatura clara: a do ator que se assume não só como executante, mas também como autor do espetáculo. Essa ação surte efeitos entre o público e a comunidade artística teatral que transformam de muitas maneiras, como menciona Zapata (2011), as representações que se constroem do indivíduo autor e da obra artística. Sobre isso, Barthes (2004) assinala que "[d]ar um Autor a um texto é impor a esse texto um mecanismo de segurança, é dotá-lo de um

11 Em outra direção, alguns artistas preferem assinar todas as funções e mantê-las especificadas e diferenciadas umas das outras. É o caso do ator Ricardo Castro e sua peça $R \$ 1,99$. No espetáculo, Castro assina como diretor, dramaturgo, intérprete, figurinista, sonoplasta, cenógrafo, iluminador e até bilheteiro. 
significado último, é fechar a escrita" (p. 4). No caso deste processo de pesquisa e criação, o efeito de dar um autor causou o contrário ao apontado pelo filósofo francês. Mostra disso foi o apresentado na seção anterior a partir da aparição da ficção autobiográfica paralela, a qual não só transformou a proposta do espetáculo, mas também a imagem que o público constrói do seu autor. A ação da assinatura, em vez de fechar a produção de significado, dotou a enunciação discursiva de outras leituras e, inclusive, ficcionalizou a existência do seu autor. Não se pode negar que, ao atribuir uma ficção autobiográfica à obra, o público acabou criando também uma representação vital muito particular do seu autor. Com a assinatura, essa ambiguidade entre criador e criatura, que já existia na cena, acabou se transferindo ao âmbito do "real", o que delatou o mito do autor, aquele que, mesmo tendo uma vida que antecede à obra, só começa a existir a partir dela.

Foi muito relevante para esta pesquisa constatar que a figura do autor não passa de ser construção social, o que dá novo sentido ao asseverado por Barthes (2011). Não é o indivíduo Juan David González Betancur como ele mesmo se reconhece o autor do unipessoal Meus caros amigos. São as diversas representações dele as que acabam assinando e reivindicando a autoria do espetáculo. Quem é González Betancur enquanto ser humano deixa de ser uma questão determinante para o espectador; ele só existe enquanto criador da obra, e é ela a que define as particularidades dele.

Dar um nome de autor, nessa lógica, é simplesmente dotar a obra de umas características particulares em um jogo de reciprocidade entre o que esse nome de autor contribui para a obra e o que ela contribui para a construção do autor. É por isso que Niels Buche-Jepsen (citado por Zapata, 2011, p. 41) sugere que, em vez de dizer "esse texto tem um autor", deveríamos dizer "esse texto está autorado", o que significaria aceitar o fato de que se trata de um discurso que tem sido não só legitimado (segundo as categorias do meio no qual se inscreve), mas também provido de um valor, de uma marca honorífica. Na proposta de BucheJepsen, reconhece-se a existência da função autor como categoria que contribui para a valorização da obra sem adjudicar nem reclamar nenhum tipo de propriedade sobre os discursos de parte da pessoa autor. 
A ação de assinar como autor de Meus caros amigos deixa de ser, assim, sob essa óptica, a reivindicação de um tipo de propriedade sobre o discurso ou a imposição de uma univocidade que explique a obra -o que tentaria constantemente a crítica tradicional que vai atrás do encontro do autor segundo Barthes (2004) —, mas a tentativa de prover tanto o espetáculo quanto a possibilidade de criá-lo de maneira unipessoal de um valor que distinga ambos os atos como experimentação cênica e criação artística. Além disso, assinar significa particularizar a obra como objeto criativo único, distinguível de outros, e detentor de uma certa lógica. Sobre o assunto, vale a pena anotar:

[d]ar nome de autor a um texto é dizer que foi escrito em um momento da história particular, que possui uma unidade de estilo que o faz singular e irrepetível, que pode ser agrupado entre umas obras completas de uma forma mais ou menos coerente e que, por sua vez, pode ser catalogado dentro de um grupo de obras com as que guarda eventualmente certas filiações formais, temáticas ou simplesmente geracionais. (Zapata, 2011, p. 41, tradução minha)

Assumir-me como autor do meu espetáculo inaugura um projeto autoral que não acaba com Meus caros amigos. Essa primeira assinatura se constitui como marca distintiva de futuros espetáculos unipessoais que poderão ser agrupados e catalogados de acordo com as possíveis similitudes estilísticas ou formais (tarefa que corresponderá à crítica). Do mesmo modo que se agrupam diferentes espetáculos encenados sob o nome de um grupo ou companhia teatral para demonstrar as relações estéticas particulares que os conectam, a assinatura pessoal pode constituir a mesma ferramenta no caso de obras produzidas por atores que se reconhecem a si mesmos como autores dos seus espetáculos ${ }^{12}$.

No entanto, é importante reconhecer que a assinatura do ator como autor do espetáculo pode ser uma ação que encontra ainda

12 É o que acontece com o trabalho de Denise Stoklos. Já são muitos os espetáculos que a atriz brasileira tem assinado com seu nome próprio. Além de estudar o conjunto de sua obra do ponto de vista estético, valeria a pena estudar toda a sua produção e as ações que acompanham suas propostas cênicas (as 
resistências no grêmio teatral. Foi o que aconteceu com a estreia de Meus caros amigos em espanhol. Como pode se observar no cartaz de divulgação do Pequeño Teatro de Medellín (Colômbia) (Figura 15), Meus caros amigos aparece como um espetáculo órfão. Ao contrário das outras peças que aparecem na programação da sala, o espetáculo produto desta pesquisa aparece como uma obra sem autor.

Figura 15. Cartaz de divulgação da temporada 2014, Pequeño Teatro de Medellín (Colômbia)

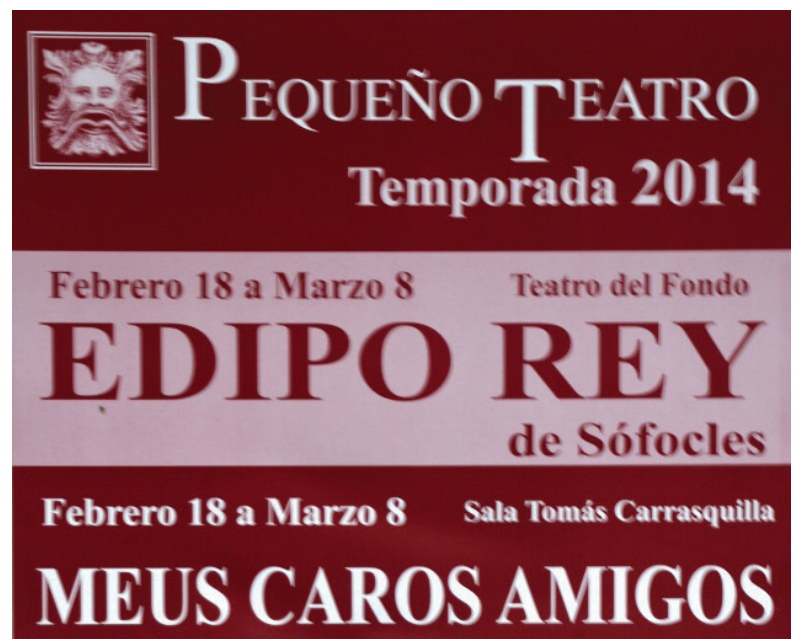

Próxima temporada 2 estrenos

Marzo 13 a Abril 12

Marzo 13 a Abril 12

EL AVARO de Molière

RÍO ARRIBA, RÍO ABAJO De Jesus Eduarde Deminguez

ENTRADA LIBRE Y SU APORTE VOLUNTARIO Martes a Sábado a las 7:30 P.M.

Carrera 42 No. 50A - 12. Tels.: 2393947 -26994 18, umw.pequenoteatro.com

(9)

maciso

IPROSPERIDAD

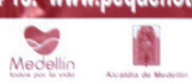

publicações que aparecem sob seu próprio selo editorial —Denise Stoklos Produções-, por exemplo) como projeto autoral. Esta pesquisa considera que, no plano comportamental, um estudo aprofundado da consolidação de Stoklos como autora teatral pode ser muito enriquecedor. 
Note-se como o título de cada espetáculo, exceto Meus caros amigos, está acompanhado do famoso "de" seguido de um nome próprio, o qual corresponde ao do dramaturgo. Claro, aparecem nomes de autores clássicos tão importantes como Sófocles e Molière (o que explicaria o uso desses nomes como atributo da qualidade da obra apresentada), mas também aparece o nome de um dramaturgo emergente na cidade (Jesús Eduardo Domínguez). A única diferença que poderia se estabelecer entre o prestígio dele ou o meu se deve a que ele assina a obra como escritor. A orfandade do espetáculo, nessa lógica, é produto de uma visão muito tradicional que continua considerando o dramaturgo autor da obra teatral, o que contradiz o que manifesta Enrique Buenaventura (1985) ao afirmar que o teatro não é um gênero literário. Nessa tradição, as funções teatrais estão muito bem definidas, motivo pelo qual o ator não deveria assinar como autor do espetáculo, já que essa honra só corresponderia ao escritor, dono do essencial: a palavra.

Que o ator assine como autor do espetáculo é, evidentemente, uma ação que continua tendo muitas resistências entre a comunidade artística teatral. É por isso que a assinatura é só uma das ações necessárias para fundamentar esse ato. No campo comportamental, é importante propiciar a discussão sobre o assunto e definir um posicionamento particular. Para este projeto autoral, é muito importante propiciar espaços nos quais se reconheçam as possibilidades autorais de atores que pretendem deixar de ser veículo ou intermediários dos discursos de outros. Por essa razão, várias outras ações têm acompanhado a criação e a divulgação do espetáculo.

A primeira delas foi a criação do blog $O$ ator em solidão. Criado com o interesse de compartilhar os avanços do processo de criação; o site se define como "blog sobre o trabalho criativo do ator que prescinde de outras figuras, como o diretor ou o dramaturgo, para alcançar a categoria de ator-autor" (González, 2013b, s/p.). Está dirigido a todos os interessados no processo particular desse unipessoal ou seguidores de trabalhos de atores e de artistas de teatro. Por um lado, é um espaço de divulgação de inquietações e descobertas do processo em si e, por outro, um site para mostrar a vida e a evolução da etapa de divulgação e recepção da peça. O blog é divulgado nas apresentações e nas temporadas de Meus caros amigos e, além de pretender contar com 
os comentários de leitores e espectadores, tem o objetivo de reforçar a ideia de criação autoral do ator.

Outras ações similares, cujo principal interesse é o de divulgar e promover a autoria do ator, são as oficinas e palestras que têm acompanhado o espetáculo por diferentes lugares e públicos. A primeira das oficinas foi a realizada no Encontro de Escolas de Teatro promovido pela Universidad Central de Ecuador, na cidade de Quito, em abril de 2013, intitulada "O ator-autor". Nessa oficina, propôs-se o conceito de materiais de criação que se defende nesta pesquisa e se ofereceu uma possível metodologia de trabalho autônomo do ator. Foi um espaço muito enriquecedor no qual, como ator-autor que iniciava seu próprio processo de criação, foi possível discutir uma ideia de autoria para o caso do ator teatral. Eu mesmo tive a oportunidade de me colocar como autor em processo, apesar das múltiplas resistências que se evidenciaram, paradoxalmente, entre os mais jovens dos participantes.

A segunda oficina foi dada já com o espetáculo formado e foi uma atividade paralela à mostra artística da programação do Palco Giratório Sesc Rondônia 2013 (Porto Velho), onde foi apresentado Meus caros amigos. Com a obra apresentada para o público geral, os participantes da oficina compartilharam seus desejos e experiências em um experimento que se intitulou "O espetáculo unipessoal como espaço criativo". A partir da estimulação à criação de espetáculos unipessoais próprios, a oficina procurou promover a descoberta de estéticas e interesses particulares e de princípios criativos que pudessem ativar a criação autônoma. A resposta à proposta de autoria do ator foi muito melhor recebida do que no Equador, talvez porque, na do Palco Giratório, os alunos puderam assistir ao espetáculo unipessoal já concluído. Também, na mesma programação, apresentei a palestra "Pressupostos teóricos do trabalho unipessoal" no Departamento de Artes da Universidade Federal de Rondônia.

Outras atividades acadêmicas similares também fazem parte do plano comportamental deste projeto autoral, como as comunicações Pressupostos para a criação do espetáculo unipessoal Meus caros amigos (VII Reunião Científica da Associação Brasileira de Pesquisa e Pós-graduação em Artes Cênicas —Abrace-, Belo Horizonte, 2013) e A questão da autoria no teatro (I Encontro Brasileiro de Pesquisa 
em Cultura, São Paulo, 2013) e a publicação do artigo O ator como intérprete (González, 2014b) na Revista Colombiana de las Artes Escénicas. Nos depoimentos apresentados nessas publicações e nesses eventos, de uma ou outra maneira, promovo e defendo as possibilidades autorais do ator e me coloco como autor do meu próprio espetáculo, ratificando a ideia de Zapata (2011) de que o projeto autoral se constrói tanto no plano textual como no comportamental. De fato, a publicação deste livro é mais uma estratégia da consolidação desse projeto autoral.

\section{Espetáculo unipessoal como experiência autoral}

Não podia concluir este capítulo sem voltar novamente a Luigi Pareyson, autor fundamental no desenvolvimento teórico da pesquisa. No intuito de encontrar um espaço autoral, minha própria experiência e minha fascinação pelo trabalho de outros atores que entravam sozinhos no palco me levaram à aproximação ao espetáculo unipessoal. Minha intuição me indicava que nele encontraria essa possibilidade.

Pareyson oferece uma perspectiva que, depois de todo esse processo de busca autoral, justifica a chegada a essa experiência cênica. Esse ponto de vista aparece no contexto da pergunta pela impessoalidade ou pela pessoalidade da arte. Para Pareyson (1997), a primeira simplesmente não existe. $\mathrm{Na}$ crítica das teorias que justificariam a suposta impessoalidade da arte, assinala:

[a]s teorias impessoalistas não se dão conta de que nada ocorre na arte senão através da mediação ativa e criadora da pessoa. Certamente, a obra de arte contém o espírito do tempo, a voz do povo, a expressão de um grupo, mas tudo isto o contém refratado na singularíssima espiritualidade de uma pessoa, porque o homem nada pensa, cumpre ou faz, a não ser pessoalmente. (p. 102) 
A arte, como qualquer atividade humana, então, não pode prescindir do seu caráter pessoal.

A arte é sempre feita por um artista, que nela derrama a própria espiritualidade, muito singular e irrepetível, ainda que nutrida pelo ambiente e pela sociedade em que vive; e a arte transfigura sempre as próprias condições, superando-as ou sublinhando-as, e delas se encontra separada por uma distância que somente o gênio criador do artista sabe preencher. (Pareyson, 1997, p. 112)

A pessoalidade é, assim, condição fundamental da atividade artística. Isso se justifica inclusive em experiências coletivas na arte. Sobre esse assunto, Pareyson (1997) propõe que “[...] os casos de colaboração não invalidam, mas antes confirmam a pessoalidade da arte, uma vez que o próprio conceito de colaboração e de trabalho coletivo implica a realidade das pessoas operantes e não a sua supressão na obra comum" (p. 103104). É surpreendente que o esteta não use como exemplo o teatro para justificar sua asseveração. Mas cita, sim, o cinema como experiência artística que "exige, de per si, contribuições coletivas, que, no entanto, não são bem-sucedidas senão quando concordam entre si, geralmente dirigidas por uma só pessoa" (Pareyson, 1997, p. 104).

Em qualquer caso, o proposto por Pareyson atinge a experiência do teatro. Como atividade coletiva por excelência, a arte teatral poderia se definir como o encontro de várias pessoalidades que trabalham pela formação de uma obra comum ${ }^{13}$. Assim, na prática mais convencional, um grupo de artistas —entre eles, atores, escritores, figurinistas, cenógrafos, músicos, dançarinos e outros tantos mais-, sob a tutela de um encenador, conformariam o que daria vida ao espetáculo como um todo.

Mas, nesta pesquisa, não se está discutindo precisamente a experiência cênica como coletiva. Pelo contrário, partiu-se de um

13 Nesse sentido, talvez a fórmula de Renato Ferracini (2014) Solo = Coletivo possa se inverter, já não para descrever a experiência unipessoal, mas sim para explicar a coletiva. Substituindo solo por pessoalidade, poderíamos pensar em uma fórmula tipo Coletivo = Múltiplas pessoalidades . 
exercício de criação que prescindiu disso. Nesse exercício, basicamente, o que se procurava era encontrar as potencialidades do espetáculo unipessoal como experiência autoral. A partir daí, descobri que a autoria se encontrava mais como a exposição da minha pessoalidade em cena. O que fiz com todos os materiais escolhidos e com todos os procedimentos autorais que utilizei na consolidação do espetáculo foi a apresentação de minha singularidade no palco ou, seguindo Renato Ferracini (2014), a coletivização dela. Com base na compreensão desse fato, e apoiado na leitura de Pareyson, consigo definir agora o espetáculo unipessoal como experimento cênico no qual prima uma pessoalidade: a do ator.

Note-se o uso do verbo primar na definição proposta. Embora o conceito de solidão tenha sido fundamental no encontro dessa pessoalidade no contexto desta pesquisa — levando à consolidação de um processo no qual não interveio criativa e diretamente nenhuma outra pessoa-, acredito que outros processos similares poderiam contar com a colaboração de outros participantes no processo de criação e conseguir resultados parecidos. A participação de um figurinista ou o uso de um texto predeterminado escrito por outro, só por citar alguns exemplos, não necessariamente opacariam a aparição dessa pessoalidade do ator.

Mas aqui foi necessário levar até o extremo a ideia de autonomia, representada na solidão da sala de ensaio, para compreender tanto intelectual quanto corporalmente a aparição dessa minha pessoalidade. No espetáculo unipessoal, o ator é a pessoalidade da obra. No contexto da arte teatral, o unipessoal seria o espaço por excelência no qual “[...] a obra é o próprio autor, solidificado numa presença evidente e eloquente" (Pareyson, 1997, p. 108). Para entender isso, precisei me afastar da experiência coletiva e procurar um estado de solidão no qual, como o poeta, encontrasse minha própria voz. Tratava-se de um encontro íntimo no qual precisei dispensar a presença de outros para entender o que se registra nas seguintes palavras:

[n]o monólogo [eu diria espetáculo unipessoal] o ator sozinho, desprovido do apoio de outros atores, acompanhado por sua ou suas personagens, realiza a comunhão mais íntima do teatro, ele 
como sumo sacerdote convoca personagens, conta histórias e entrega-se a uma plateia para mostrar, como única testemunha, seu drama ou o de outros. (Santa, 1988, p. 3, tradução minha)

Não teria conseguido chegar a essa compreensão nem à definição de espetáculo unipessoal sem a experiência prática e é ela, também agora, que me permite com maior clareza prescindir do uso do termo solo. Como apresentei no primeiro capítulo, a palavra solo se relaciona mais diretamente com o assunto da execução de um indivíduo só, o que não me parecia suficiente para explicar os alcances desse tipo de experimentação cênica. Além disso, a experiência como espectador me permitiu assistir a vários "solos" no quais, por exemplo, o ator interatuava diretamente com a plateia, e o cenário acabava sendo um grande espaço onde plateia e ator conviviam placidamente. Embora o espectador não entre no espaço de ação física do ator na proposta de Meus caros amigos, a interação e o diálogo constante com a plateia fazem com que essa ideia de solidão no palco seja tão contraditória como a de monólogo, lembrando o afirmado por Anne Ubersfeld (2005). Não existe a solidão no palco. Nem mesmo o ator que trabalhe com a ideia mais clássica de quarta parede pode dizer que se encontra sozinho no cenário.

Quando falo de autoria em termos de exposição de uma pessoalidade e defino espetáculo unipessoal como experimento cênico no qual ela encontra seu espaço, estou deixando claro o porquê de não se reduzir o assunto ao executante. Pareyson esclarece o tema quando, usando como ponto de partida o discurso de Benedetto Croce, estabelece a diferença entre o que seria a pessoalidade artística e a pessoa do artista.

A primeira é singular e original precisamente porque se destacou da comum e genérica humanidade para individuar-se numa obra de arte e coincide, sem resíduo, com a obra, única a existir e a partir da qual, apenas, é possível definir a personalidade de um artista enquanto tal. A segunda é o fundo comum e indistinto da humanidade, a individualidade biológica é informe, vã, fugidia e inexistente na sua móvel e instável fluidez, na qual é impossível fazer consistir a ideal personalidade de um artista e, em geral, o 
valor de uma pessoa operante e operosa. A pessoalidade, portanto, adquire o seu caráter de individualidade, determinação, originalidade, somente enquanto acolhe em si a universalidade, totalidade, cosmicidade do espírito e se distingue da indistinta e indeterminada humanidade das pessoas múltiplas e vivas. (Pareyson, 1997, p. 101-102)

Nessa direção, a ideia de execução estaria reduzindo o assunto à pessoa do artista (eis o sentido do termo solo). É por isso que a expressão espetáculo unipessoal acaba sendo mais abrangente e acolhendo um sentido mais próximo da ideia de formação da obra de arte. Finalmente, o que outorga o caráter de pessoalidade se relaciona com o exercício do criador de se individualizar na obra, e sua personalidade artística só pode ser definida a partir da obra em si. Por isso, pode-se afirmar:

E se no operar artístico a pessoa do autor tornou-se, ela mesma, o seu próprio e insubstituível modo de formar, e se a arte não tem outro conteúdo que não a própria pessoa que é sua energia formante, bem se pode dizer que a obra, a que o processo artístico leva a cabo, é a própria pessoa do artista encarnada completamente num objeto físico e real, que é, justamente, a obra formada. (Pareyson, 1997, p. 107, itálico no original)

Essa última afirmação de Pareyson justifica completamente essa busca, inicialmente conduzida só pela intuição, do espetáculo unipessoal como espaço autoral. Dadas as condições coletivas habituais do exercício teatral, o espetáculo unipessoal se constitui como aquele lugar privilegiado no qual o ator pode se tornar ele mesmo, como singularidade formante, como pessoalidade a ser exposta, seu "próprio e insubstituível modo de formar". A ideia de pensar em uma categoria ator-autor para diferenciar as particularidades do processo de atores que escolhem a criação de unipessoais, então, não se torna tão desacertada.

Na proposta de Meus caros amigos, posso identificar meu processo como ator e autor do espetáculo na medida em que fui tanto executante (a pessoa do artista) quanto criador (o próprio modo de formar, pessoalidade artística), mas não fui ator e autor de maneira separada, 
fui unidade formante. Portanto, no panorama do espetáculo unipessoal, defino a categoria de ator-autor como aquele que, sem deixar o lugar central da cena como executante da ação, se constitui como principal agente na criação da obra cênica. Desse modo, categorias como a de ator-encenador ou ator-dramaturgo, além de continuarem separando as funções habituais, são insuficientes pela mútua exclusão que demandam os termos em cada caso.

É claro, pois, que a busca empreendida nesta pesquisa permitiu o desenvolvimento de certas ideias que a intuição tinha colocado no meu caminho profissional e artístico. No entanto, a própria prática e a exploração teórica que ela demandou demonstraram que existiam algumas nuances que não tinha contemplado. Registra-se aqui uma passagem de intérprete a autor da cena, a qual encontra um espaço autoral para o ator no espetáculo unipessoal. Trata-se, finalmente, da exposição de um processo criativo cuja lógica só pode atingir as necessidades particulares de um artista de teatro, mas que, acredito, pode contribuir para as reflexões da experiência unipessoal de outros. 
